\title{
«ЯБЛУЧНИЙ ПИРІГ» (НА ПРИКЛАДІ ІСТОРІЇ «ВЛАСНИК НАЙКРАЩОГО КЛУБУ ДЛЯ ГЕЇВ» КНИГА ІСТОРІЙ ГГМН ДЕМОКРАТИЧНОЇ МОЛОДІ» С. ЖАДАН)
}

Бабенко А. О., аспірант

Украӥна, Київ

Інститут філології КНУ ім. Т. Шевченка, Київ

DOI: https://doi.org/10.31435/rsglobal_ws/30082018/6081

\section{ARTICLE INFO}

Received: 24 July 2018

Accepted: 26 August 2018

Published: 30 August 2018

\section{KEYWORDS}

mass,

images,

freedom,

love,

life,

apple.

\begin{abstract}
The article describes the features of author's interpretation of the author's interpretation of the figurative system of the story "Owner of the best club for gays" from the book by S. Zhadan "Anthem of Democratic Youth" are considered; the phenomena of human life; apple symbol The study of this segment of the national literary space is extremely relevant, given the rather one-sided and non-systematic approach to the analysis of Serhiy Zhadan's work in general.
\end{abstract}

Citation: Бабенко А. O. (2018) ««Iabluchnyi Pyrih» (na Prykladi Istorii «Vlasnyk Naikrashchoho Klubu dlia Heiv» Knyha Istorii «Himn Demokratychnoi Molodi» S. Zhadan). World Science. 8(36), Vol.3. doi: 10.31435/rsglobal_ws/30082018/6081

Copyright: (C) 2018 Бабенко А. O. This is an open-access article distributed under the terms of the Creative Commons Attribution License (CC BY). The use, distribution or reproduction in other forums is permitted, provided the original author(s) or licensor are credited and that the original publication in this journal is cited, in accordance with accepted academic practice. No use, distribution or reproduction is permitted which does not comply with these terms.

XXI століття як в літературі так і в культурі є своєрідним викликом масової культури. Йде мова про те, що переважно масову літературу творять професійні письменники, наприклад, такі як Сергій Вікторович Жадан. Насолоду від прочитаного тексту має породжувати принцип «комфортного читання» та справдження сподівань та переживань в момент та пост процесу прочитаного. Саме запити широкого загалу, репрезентація масової літератури висвітлюється в книзі Сергія Жадана «Гімн демократичної молоді», в якій виокремлюючи головне слово «демократичної» все розуміється на засадах народу (масовості), свободи та сили. В одному зі своїх інтерв'ю з Тетяною Терен Сергій Жадан відповів на запитання, що він розуміє під словом «свобода»: « Свобода - це можливість робити те, що хочеш , не заважаючи при цьому нікому іншому» [1, с.243].

Актуальність дослідження зумовлена відсутністю грунтовного дослідження як усієї книги «Гімн демократичної молоді» С.Жадана, так і окремих історій з неї.

Мета дослідження - інтерпретація образної системи історії «Власник найкращого клубу для геїв» 3 книги С. Жадана «Гімн демократичної молоді».

Наукова новизна роботи полягає в тому, що вона $\epsilon$ спробою грунтовного аналізу образної системи історії «Власник найкращого клубу для геїв» 3 книги С. Жадана «Гімн демократичної молоді».

Відкриваючи книгу з яскравою та епатажною обкладинкою варто звернути увагу на міні анотацію: ««Гімн демократичної молоді» - шість ліричних історій про розвиток середнього бізнесу в умовах формування відкритого суспільства. Сюжет книги поєднує в собі ліричну оповідь із фаховими публіцистичними розвідками, присвяченими легалізації тіньового сектору економіки. Все, що ви хотіли знати про дружбу і вірність менеджерів середньої ланки, але не знали в кого спитатись. Ідеальне чтиво для домогосподарок» [2, с.2]. У першій історії «Власник найкращого 
клубу для геїв» знаходимо відголоски анотації, що мова буде йти саме про легалізацію тіньового сектору економіки, «вільної ніші» - клубу для геїв, що в часи СРСР було ксенофобським явищем. На перших сторінках знаходимо філософськи роздуми, що ж є сенсом життя: «Одного ранку ти прокидаєшся і раптом розумієш, що все погано, все дуже погано. Ще зовсім недавно, скажімо, вчора, ти мав можливість щзось змінити, поправити, пустити вагони іншими коліями, але тепер усе - ти лишаєшся осторонь і більше не впливаєш на події, щуо розгортаються навколо тебе, мов простирадла. Ось ие почуття безпорадності, відстороненості й відлучення людина відчуває, очевидно, перед смертю, якщуо я вірно розумію концепцію смерті, - ти ніби все робив правильно, ти все тримав під контролем, чому ж тебе намагаються відключити від покручених червоних дротів системи, вбити, як файл, і вичистити, мов підшкірну інфекцію, чому життя, в якому ти щзойно брав безпосередню участь, прокочується, наче море, у східному напрямку, швидко віддаляючись і залишаючи по собі сонще повільного вмирання. Несправедливість смерті особливо гостро відчувається за життя, ніхто не переконає тебе в доиільності твого переходу на територію померлих, у них просто не вистачить аргументів для цуього. Але все погано, ти раптом сам починаєш у че вірити, усвідомлюєш $і$ затихаєш, і дозволяєш якимось шарлатанам, алхімікам $i$ патологоанатомам вирвати твоє серце $i$ показувати його на ярмарках $i$ в кунсткамерах, дозволяєш ӥм проносити його під полою для проведення сумнівних експериментів та відправлення безрадісних ритуалів, дозволяєш їм говорити про себе як про померлого і крутити в прокурених пальиях своє серие - чорне від утраченої любові, легких наркотиків і неправильного харчування» [2, c.3-4]. Сенс життя втрачається коли в тебе в першу чергу нестача любові та бабок, а потім вже кисню, нерв та статевого дозрівання: «Насправді ніхто не помирає від нестачі кисню, помирають саме від нестачі любові або нестачі бабок. Коли одного разу ти прокидаєшся і розумієш, щуо все дуже погано, вона пішла, щее вчора ти міг зупинити ї̈, міг усе виправити, а сьогодні вже пізно, $i$ тепер ти лишаєшся сам на сам із собою, $i$ ї̈ не буде найближчих років п'ятдесят, а то й шістдесят, ие вже наскільки вистачить у тебе бажання $і$ вміння без неї прожити. I від усвідомлення цзього тебе раптом накриває великий $і$ безмежний відчай, $і$ піт виступає, мов клоуни на арені, на твоій нещасній шкірі, і пам'ять відмовляється співпрацювати з тобою, хоча від цзього теж не помирають, від иьього навпаки - відкриваються всі крани і зриває всі люки, ти говориш: усе нормально, я в порядку, витягну, все гаразд, $і$ кожного разу боляче б'єшся, потрапляючи в ті порожнини, які утворились у просторі після неї, в усі изі повітряні тунелі й коридори, котрі вона заповнювала своїм голосом $і$ в котрих тепер заводяться монстри й рептилії ї̈ відсутності, все нормально, говориш, я витягну, я в порядку, від цьього щуе ніхто не помирав, щзе одну ніч, щуе кілька годин на територіях, всіяних чорним перцем, битим склом, на гарячому піску, перемішаному 3 гільзами і крихтами тютюну, в одязі, який ви носили з нею разом, під небом, яке залишилось тепер тобі самому, користуючись ї̈ зубною шіткою, забираючи до ліжка ї̈ рушники, слухаючи ї̈ радіо, підспівуючи в особливо важливих місиях, там, де вона завжди мовчала, проспівуючи иі місия за неї, особливо коли в пісні йдеться про речі важливі, такі як життя або стосунки з батьками, або релігія врешті-решт» [2, с.5-6]. Одна 3 основних ліній в цій історії це не локус гей клубу, а розуміння того, що як не крути в цьому житті ти один, про слово «підтримка» варто забути; ти станеш нікому не потрібним зі своїми боргами, неправильним бізнесом та любов'ю, економікою та сексом - це перетвориться на «тахікардію для піонерів та валютних бірж»: «...nрокинувшись одного разу і несподівано усвідомивщи, щзо в житті немає нічого, крім твоєї душі, твоєї любові, $і$ твого, блядь, боргу, який ти ніколи не зможеш повернути, принаймні в изьому житті» [2, с. 8].

Сюжетна лінія даної історії досить проста: Сан Санич, який належав до асоціації «Боксерів за справедливість», інакше кажучи був «віджималою та кришою» у такому собі середньому бізнесі та його друг Георгій Давидович (Гога) вирішують знайти своє місце у вирі вседозволеності. Сан Санич виходить з бізнесу «Боксерів» із-за однієї прикрої ситуації, яка дала йому поштовх замислитись над своїм майбутнім: «Одного разу, перебуваючи в стані тривалого алкогольного ступору (очевидно, мова йшла про якісь свята, скоріш за все про Різдво Христове, мені так здається), підопічні Санича вирішили подарувати своєму молодому босу бронежилет. Бронежилет вони виміняли в працівників Київського РВВС на новий ксерокс, машину останнього покоління. Подарунок тут-таки обмили, після чого вирішили випробувати. Санич одягнув бронежилет, бійці дістали «Калашникова». Бронежилет виявився надійною итукою - Санич вижив, отримавии всього три кульові поранення середньої тяжкості. Але вирішив на изьому зупинитись - кар'єра вільного бория йому не вийшла, кар'єра бория за справедливість та соціальну адаптащію складалась теж не найліпшим чином, nотрібно було щзось міняти» [2, с. 17]. Сан Санич та Гога були однокласниками, потім Санич потрапив до борців, а Гога в медичний, погорівши на анестетиках. Пафос цієї зустрічі в тому, що Гога втомився від незрозумілих ситуацій у своєму житті: бізнес у чотирьох країнах, розшук у 
прокуратурах, аліменти вдові в Північній Інгушетії, вагони гіпсокартону та інше. Гога лиш бажав одного: Усе життя мені хотілось мати свій клуб, розумієш, свій клуб, в якому я зможу сидіти кожного вечора $i$ звідки мене ніхто не викине, навіть якщзо я почну ригати в меню» [2, с. 18-19]. Наступного ранку Гога та Сан Санич зустрілися у кафе-клубі «Бутерброди» зі своїм артдиректором Славіком. Саме Славік подав ідею щодо гей клубу, тому що найголовніше - це був формат:« Клубний бізнес, - почав він здалеку, - справа стрьомна, пери за все тому, щэо ринок вже сформований, розумісте, про щзо я?

Хочете зробити фаст-фуд - робіть фаст-фуд, але в місті вже є сто фаст-фудів, хочете кабак - давайте кабак, я культурну програму влаштую, ие без проблем, хочете диско давайте диско, хочете паб - давайте паб. Тільки ні фіга у вас не вийде, Георгію Давидовичу, ви вже вибачте, щзо я так відверто, ні фіга. Це ж чому? - ображено запитав Гога. Тому щзо ринок вже сформований, $і$ вас просто задушать» [2, с.22-23]. Славік зауважив, що потрібно зайняти вільну нішу, яка була лише одна - гей клуб. Сан Санич та Гога погодились на цю авантюру. Славік був ще тим «торчком». Він викликався зареєструвати клуб як клуб молодіжних ініціатив, для того щоб не платити за комерційну діяльність. Відкриття клубу відбулося на початку червня. Гога запросив партнерів по бізнесу, друзів дитинства, братів Лихуїв та маму. Відкриття було феєричним: мама пішла незабаром із-зі гучної музики, Слава та Гриша Лихуї вчинили мордобій в туалеті з оптивиками, в свою чергу оптовики та «нормальні люди» поїхали туди де є стриптиз та випивка. Зосталися лиш справжні представники клубу «Бутерброди» - це Доктор і Буся (геї) та Віка. Віка була лесбіянкою та вкотре замовила чергову горілку. Вона мала металевий пірсинг на обличчі, «назюзяний» вигляд та подругу-лесбіянку, котра покинула їі та поїхала до Туреччини. Незважаючи на все це Сан Санич та горбань (таксист) наважились довести іiі додому; адресу Сан Санич знайшов у паспорті Віки, який лежав у внутрішній кишені їі косухи. Сан Санич «розраховував» на щось з Вікою, але: «Якщо хочеш, - сказав Санич, - я залишусь у тебе. Чувак, - відповіла йому Віка, вдоволено посміхаючись, - я ж лесбіянка, ти щзо - не розумієш? А ти навіть не гей, ти власник. Січеш? Віка поцілувала його $і$ зникла за дверима. Санич відчув на вустах холодний присмак ї̈ пірсингу. Враження було таке, ніби він торкнувся губами срібної ложки» [2, с. 32].

Наступного ранку почалися трудові будні. Найголовніша проблема в них була - це те, що бізнес не йшов і був взагалі неприбутковим. Арт-директор знайшов «вихід» 3 ситуації. Славік домовився, що в гей клубі будуть проводитись «Вишивані рушнички» — це конкурс дитячої та юнацької творчості, який проводиться під патронатом губернатора, башляється 3 бюджету, що ніяка податкова не буду мати претензій. Георгій Давидович та Сан Санич погодились на чергову «авантюру» Славіка, адже: «...pозпишемо програму, бабло проведемо через бухгалтерію, зробимо відкат пожежникам, щзоби вони нас у бюджет на наступний рік поставили, і все - цілий рік кавеенити будемо за народні бабки, шов маст го он, Георгію Давидовичу, я в цььому бізнесі двадиять років, ай, блядь! - закричав він» [2, с. 36].

По обіді в «Бутерброди» прийшли четверо, називаючи себе «Суперксероксами». Гога та Санич не зрозуміли, що відбувається. Четверо кажуть, що вони лідери на ринку та потрібно платити «новачкам» за те, що займають територію «Суперксероксів». Гога почав кришувати себе братами Лихуями, а у відповідь отримав: «Лихуї?! Ці лохотронщики?!! Та вони у нас, в «Супер-ксероксах», взяли партію старих принтерів $i$ перепродали їх якимось мудакам із Тракторного! Сказали, щчо це копіювальні машини нового покоління! $A$ ті зіпхнули їх в ментовську академію, оптом, із нашою гарантією. Ми ледве відмазались!!! Лихуі!!!! Лихуї!!! Другий рвав на собі синю спортивну куртку $і$ вигукував на весь клуб прокляте прізвище» [2, с. 38]. Ситуацію врятував Славік, який вбігаючи до клубу кричав, що замовлення на «Вишивані рушнички» їх. Четверо почувши це почали потрохи «виповзати» 3 клубу зі словами: «...так вас щуо, в натурі губернатор «кришує?» [2, с. 40].

3 клубом справи складалися все гірше й гірше. Після «успішно» проведених «Вишиваних рушничків» Славіка ледь не набили, Гога рахував збитки, Віка не відповідала на дзвінки. Санич подумував про «Боксерів за справедливість». Одного ранку після шоу-програми 3 Раїсою Соломоновною («...це циганський муніципальний ансамбль, заслужена артистка Білорусі» [2, с. 44] Гога майже здався: «Мені скоро тридиять, я нормальний здоровий бізнесмен, на мене тьолки вішаються. Ну, добре, знову подумав він, тьолки не вішаються, але все одно - для чого мені цей клуб, для чого мені иі геї, щзо я сам собі життя псую. Він потягнувся за телефоном, набрав номер знайомого оптовика і з льоту купив у нього партію гіпсокартону» [2, с. 51-52].

Останнім фіаско було гейське Купала 3 клоунами Іваном та Петею Бичками. На свято були запрошені партнери по бізнесу, оптовики, друзі дитинства та брати Лихуї, з яких прийшов 
лише Гриша, бо Саву побили і він лежав у лікарні. Все закінчилось знову ж таки мордопобиттям. Гриша, який вже прийшов випивший звалив одного $з$ офіціантів та охоронці почали його бити. «Гриша Лихуй, образившись на всіх $і$ не маючи більше сил опиратись, dicтав із китені піджака ручну гранату і кинув ї̈ в крайню кабінку. Унітаз тріснув, як волоський горіх, з кабінки повалив дим, публіка кинулась на вихід» [2, с. 60-61]. Апофеозом цієї події було те, що касир утік з усією виручкою. Горбань та Гога мчали за ним на автівці, але не догнали. Натомість, вони влетіли в кіоск із газетами.

За місяць Гога розпочав новий бізнес з ігровими автоматами. Горбань тепер був його компаньйоном та касиром. Славік з Раїсою поїхали на Далекий Схід, а Сан Санич вийшов з бізнесу.

На початку серпня Санич зустрів Віку, яка мала новий пірсинг та не дала ранам загоїтись. Вона збиралася до Туреччини до своєї коханої.

Через деякий час Санич отримав повідомлення від друзів-геїв - Доктора та Бусі. Сан Санича хвилювало одне запитання, яке він поставив Бусі: «А як же фізіологічний бік між вами?». На що Буся дав відповідь: « Ти розумієш, Сашо, в чому річ, в принципі, це ж не так $і$ важливо, ну, я маю на увазі фізіологічний бік, розумієш мене? Головне ж в іншому. I в чому? - запитав його Санич. Головне в тому, що він мені потрібен, розумієш? І я йому потрібен, мені здається. Ми проводимо разом увесь свій час, читаємо разом, ходимо в кіно, бігаємо разом ураниі» [2, с. 65]. Санич розповів Бусі про Віку, про те, що вона лесбійка, що вони мали секс, що вона звалила до Туреччини. Буся йому пояснив, що варто розмежовувати любов та секс: «Ну, грубо кажучи, секс - це коли ви трахаетесь, і ти після иього хочеш, аби вона якомога скоріше пішла. А любов, відповідно, - це коли ви трахаєтесь, і після траху ти хочеш, аби вона якомога надовше залишилась» [2, с. 67].

Насамкінець Буся простягнув Сашку яблучний пиріг, який Доктор спік спеціально для Бусі. Варто розібрати символ «яблука» як найголовніший та наскрізний у цій історії. В Свропі яблуко раю, тобто з дерева пізнання добра і зла, $є$ символом спокуси і гріха. На картинах про гріхопадіння прабатьків (Адама і Єви) змія тримає в роті яблуко, хоча в тексті мова йде просто про «фрукти», «плоди». Картини про народження Христа показують немовля Ісуса, який бере яблуко; символічно він, таким чином, бере на себе гріхи світу, тому яблука на різдвяній ялинці можуть тлумачитися як можливість повернення в рай завдяки народженню Христа. Але спочатку приваблива солодкість яблука асоціювалася зі спокусою гріха i через схожість латинського слова (malus - яблуня) зі словом malum - поганий, злий, гріховний. Тому в творах мистецтва епохи бароко нерідко смерть у вигляді скелета тримає в руках яблуко: ціна Гріха - смерть.

Яблуко у християнській традиції має подвійне значення. 3 одного боку означає зло (латинською malum) i є плодом спокушання Адама і Єви. 3 іншого боку, зображений з Христом або Дівою Марією, воно вказує на нового Адама і на порятунок.

Н. Науменко вказує на те, що: «Одним із найдавніших рослинних символів украйнськоі культури справедливо вважається яблуня. Бог створив ідеальну яблуню - Дерево життя, ї ивітіння - «ніжна молитва про майбутне плодоносіння». А плід ї̈ - яблуко - це символ цілісності, земних бажань попередження про шкідливість переситу; символ початку всіх речей, плодючості; безсмертя та вічної молодості» [3, с. 1]

Отже, символ яблука $є$ дуальним. Важко констатувати та зрозуміти який з сенсів тут $\epsilon$ домінуючий - добро чи зло. Все ж таки Сан Санич забрав той пиріг та поділився ним 3 собакою; вийшло майже порівно: «На честь міжнародного свята солідарності геїв та лесбіянок тобі дістанеться яблучний пиріг! Пес задоволено облизнувся» [2, с. 67]. Що ж таке «любов?». Сергій Жадан дав відповідь на це: «Любов належить до тих речей, які найменше піддаються самоконтролю» [1, с. 243].

\section{ЛIТЕРАТУРА}

1. REСвізити: антологія письменницьких голосів. Книга перша / Тетяна Терен ; світлини Олександра Хоменка. - Львів : Видавництво Старого Лева, 2015. - 280 с. - ISBN 978-617-679-190-4

2. Жадан С. Гімн демократичної молоді / Сергій Жадан. - Х. : Фоліо, 2006. - 223 с. - (Графіті).

3. Науменко, Н. В. Яблуко як символ української фольклорної та книжної поезії / Н. В. Науменко // Література. Фольклор. Проблеми поетики : зб. наук. праць, присвячений дослідженню творчої спадщини Лідії Дунаєвської. - К. : «Київський університет», 2010. - Вип. 34. - С. 292-298. 